\title{
A corroboree for the Countess of Kintore: Enlivening histories through objects
}

\author{
Gaye Sculthorpe
}

This paper discusses a corroboree performed in Darwin in 1893 to illustrate the potential of British ethnographic collections for researching overlooked historical events. The performance was brought to light after a collection of Aboriginal artefacts used in it was noted and examined by the author in the collections of Marischal Museum, Aberdeen, in 2016. The description of the performance and associated objects extends understanding of the nature of cross-cultural engagements in late nineteenth-century Darwin and raises museological questions about methodologies for engaging Aboriginal people in the research and interpretation of historic objects. ${ }^{1}$

Since 2015, I have been regularly visiting regional museums in Great Britain and Ireland to identify significant Aboriginal and Torres Strait Islander items in their collections and to assist local curators document these. Such collections remain relatively unknown despite surveys undertaken and the number of researchers who have examined these collections over many decades. ${ }^{2}$ In 2001, Philip Jones estimated that there were perhaps 30-40,000 Aboriginal and Torres Strait Islander

\footnotetext{
1 Readers are warned that this paper contains quotes from nineteenth-century newspaper accounts that include offensive terms used to refer to Aboriginal people in that era. A previous version of this paper was delivered as the 2017 Anthony Forge Memorial Lecture at The Australian National University. I would like to thank Ingereth Macfarlane as editor of the journal and the anonymous referees for their comments. Thanks also to Philip Jones of the South Australian Museum in accessing the diary of Edward Stirling; Louise Wilkie and Neil Curtis for assistance during my visit to view the collection at Marischal Museum; and Kirsty Kernohan for discussions regarding the Kintore archives.

2 Researchers who have published on Aboriginal and Torres Strait material in UK collections include Plomley 1961, 1964; McBryde 1978; Moore 1984; Morphy and Edwards 1988; Megaw 1993, 1994; Philp 2015. Surveys include Gathercole and Clarke 1979; Cooper 1989; and Jones 2001. The Gathercole and Clarke survey is available online, unesdoc.unesco.org/images/0004/000473/047346EB.pdf (accessed 27 July 2018).
} 
objects in European museums. ${ }^{3}$ With data provided to me by individual museums, collection data available online and by examining past surveys, I have estimated that there are over 30,000 Australian Aboriginal and Torres Strait Islander objects in British and Irish collections. ${ }^{4}$ These collections are particularly important since they include many object types that are not well-represented in Australian collections or that were collected at a time before some Australian states had their own museums.

Historical approaches to researching Aboriginal collections in museums have great value. For example, in Britain the Pitt Rivers Museum, using the concept of 'the relational museum', analysed objects acquired between 1884 and 1945:

to provide insights into the colonial relations of administrators, missionaries, travellers and anthropologists, the changing situations of local people responding to and participating in these colonial forces, shifting intellectual fashions in the metropolitan centre lying behind collections and a mass of biographies of people of all types whose lives were entangled with objects and collections. ${ }^{5}$

The project demonstrated the potential for museum collections as 'sources of complex histories and as a means of activating relationships in the present' . Jones, in Ochre and Rust, drew on museum objects to develop narratives about meanings of objects on the colonial frontier. More recently, Rebe Taylor has examined the life and work of Ernest Westlake through a study of his collections and archives at the Pitt Rivers Museum. ${ }^{7}$ Recent re-examination of an early Aboriginal shield from New South Wales in the British Museum highlights how even one object can be used to animate past histories and to act as a potent force in engaging with Indigenous Australians and others today. ${ }^{8}$

My first visit to a regional collection in the United Kingdom was in 2015 to the Royal Albert Memorial Museum in Exeter. To my great surprise, I located there Aboriginal artefacts used by the Aboriginal cricketers in cultural performances during the 1868 Aboriginal cricket tour of England. The tour manager, William Hayman, had donated these to the museum at the end of the tour, which was the year the museum opened. ${ }^{9}$ In mid-2018, some of these were displayed at the MCC Museum at Lords Cricket Ground to commemorate the 150th anniversary of this historic event.

\section{Jones 2001: 5 .}

Of this total, approximately 13,000 are stone tools collected by Ernest Westlake in the Pitt Rivers Museum, Oxford.

5 Gosden et al. 2007; also Pitt Rivers Museum, 'The Relational Museum', www.prm.ox.ac.uk/RelationalMuseum. html (accessed 21 July 2017).

6 Pitt Rivers Museum, 'The Relational Museum'.

7 Jones 2007; Taylor 2017.

$8 \quad$ Nugent and Sculthorpe 2018; Thomas 2018.

9 Sculthorpe 2016. 
The regional museum research has involved to date over 25 museums. It seeks to extend the concept of 'the relational museum' to explore a diversity of connections between objects in multiple institutions (local, national and international), and how new relationships can be developed by these institutions with originating communities for whom these objects may be known, or as yet unknown, but nevertheless important today. ${ }^{10}$

This paper is a first step in activating relationships in relation to a significant collection of objects noted during a research visit to Marischal Museum, University of Aberdeen, in 2016. These objects and associated archival material, unpublished and overlooked until now, draw attention to a corroboree performed in Darwin in April 1893 for the Countess of Kintore.

There is increasing interest in such nineteenth-century Aboriginal cultural performances. In his study of tourist corroborees in South Australia until 1911, Michael Parsons highlighted the grand scale of some of those events (up to 20,000 spectators) and suggested genres of performance (peace, command, gala) that could be blended to suit any required audience. ${ }^{11}$ Fred Cahir and Ian D. Clark have demonstrated how Aboriginal people on the goldfields of Victoria in the mid-nineteenth century displayed increasing business acumen when participating in such events. ${ }^{12}$ More recently, Janice Newton has argued in relation to two Victorian corroborees that these particular events were examples of creative responses to the great changes happening to the lives of Aboriginal people during that period. ${ }^{13}$ While corroborees were sometimes performed on the lands of the Aboriginal participants, in other cases, such as with Meston's 'Wild Australia Show', Aborigines were involved in cultural performances that toured widely in the $1890 \mathrm{~s}$ and early 1900s. McKay and Memmott have argued that by presenting Aborigines as 'the other', Meston helped legitimise legislative reforms aimed at controlling the lives of Aboriginal people in Queensland. ${ }^{14}$ Although arranged performances of public 'corroborees' in Darwin - such as for the Earl of Kintore in 1891 - have been noted previously, the discovery and consideration of objects and associated archival material from the 1893 corroboree for the Countess of Kintore extends our understanding of such events.

10 ARC Linkage Grant LP150100423 titled 'The Relational Museum and its Objects' led by Professor Howard Morphy and Dr Maria Nugent of The Australian National University. The research partners are the British Museum, the National Museum of Australia and Wagga Wagga City Council.

11 Parsons 1997.

12 Cahir and Clark 2010.

13 Newton 2017.

14 McKay and Memmott 2016: 200. 


\section{Vice-regal corroborees in Darwin}

In the early 1890s, a series of vice-regal visitors to Port Darwin (then Palmerston) gave rise to more frequent demands by European officials for Aboriginal cultural performances to entertain these transient audiences. As historian Samantha Wells has noted, these were not the first Aboriginal performances for a European audience in Darwin, ${ }^{15}$ but the 1890 s was a period of particular intensity, influenced by Port Darwin then being a frequent stopover on shipping routes to Asia. Contemporary descriptions and surviving objects provide insights into the organisation of the performances, the complex nature of the material culture produced and exchanged for them and insights into their values and meanings to those involved. No Aboriginal oral or written accounts of these events exist, but Aboriginal actions and values can be inferred from the European descriptions of the events, observations of the objects used and collected, and by inference from observations of other ceremonial gatherings in northern Australia in that period.

Memorialised by several photographs taken of the event by photographer and police Inspector Paul Foelsche, a vice-regal corroboree was arranged in 1891 for the 9th Earl of Kintore, Algernon Keith-Falconer, then governor of South Australia. At the request of the British Colonial Office, Kintore made a tour of inspection of what was then part of South Australia, including a transcontinental trip from Darwin to Adelaide with Edward Stirling, honorary director of the South Australian Museum. They were accompanied by three Aboriginal men, Willie, Jem and Louis. ${ }^{16}$

Kintore's visit to the Top End included a three-day boat trip up the Alligator River and travelling with the Government Resident Mr John Knight and Foelsche to inspect the goldfields near Pine Creek. ${ }^{17}$ The Resident played a key role in the social life of Darwin and was host for important visitors. Knight had emigrated from England to Melbourne in 1852 after seeing the Great Exhibition in London in 1851, and had organised the exhibits from Victoria for the 1862 International Exhibition in London. ${ }^{18}$ In $1888-89$, he was the Northern Territory commissioner for the Intercolonial Centennial Exhibition in Melbourne. ${ }^{19} \mathrm{He}$ had developed a reputation for flair in organising such displays. Foelsche had been working in the region since 1869 and, as Povinelli has described, held a complex position as both

15 Wells 2003: 165-74.

16 The names are taken from the online catalogue of a photograph of the expedition in SAM Archives, ref. AA 309/5/1/30. One of these men was also present at the 1893 corroboree (see below), but their life stories await investigation.

17 Adelaide Observer, 4 July 1891.

18 Rosenzweig 1996: 25; see also letter from J G Knight to Emilie Knight in Wilson et al. 1994: 25.

19 Wilson et al. 1994: 14. 
a dispenser of justice and a 'key interpreter for the European settlers of the status of local Aboriginal groups' traditional outlook' ${ }^{20} \mathrm{He}$ described and evaluated their customs, collected their objects and took hundreds of photographs. ${ }^{21}$

To welcome Kintore, Knight organised a special procession of the Chinese community, a banquet with the Chinese merchants and a ball. ${ }^{22}$ On 2 April, he also hosted a 'grand Aboriginal corroboree' on the Esplanade involving 'Larrakia' and 'Woolnah' people in 'opposing factions' who were decorated with 'ochre and other fantastic ornaments of fur or feather' ${ }^{23}$ A local paper reported of this event:

For the corroboree the darkies had their camp pitched opposite the Residence, and here they cut their antics for an hour or more to the interest and delight of the Governor and a great many other visitors who had seen nothing like it before. It was a very fair specimen of aboriginal entertainment, and its success quite justified $\mathrm{Mr}$. Knight in placing it amongst the good things of the gubernatorial season. ${ }^{24}$

The event was such a success that Mr Knight organised another shortly after for the officers and crew of the visiting ships HMS Penguin and HMS Tauranga in front of a crowd of between 300 and 400 people. The Northern Territory Times \& Gazette commented:

True to arrangement, the Government Resident tendered his complementary corroboree in honour of the two warships. It was arranged in tip top style, with all that regard for detail which characterises the entertaining efforts of Mr. Knight on all occasions. As a performance the corroboree was similar in most respects to the one given for the Governor's edification, but here were a few additions, mechanical and otherwise, which considerably enhanced the interest in the spectacle, and as the natives had much more time to make their arrangements, rehearse their parts, prepare costumes and so on, the effect was much nicer than on the previous occasion. The use of ship's blue lights gave the show an additional charm, and with all things combined the affair was quite a treat to the large number of visitors who had never seen anything of the kind before. ${ }^{25}$

The account commented that a corroboree in town was very different to the unique dances performed by 'unadulterated myall blacks' in their 'virgin home':

In the midst of a town the weirdness of the spectacle is rubbed off, and the performers look upon the thing as a rare fine joke... One thing at least is remarkable in connection with all these native shows is the wonderful time and tune kept by both the 'band' and the dancers ... the darkies are simply perfect in their regard for the pause ... and

20 Povinelli 1993: 77.

21 See Jones 2005 for further information on Foelsche's photography.

22 Northern Territory Times \& Gazette, 10 April 1891; Adelaide Advertiser, 24 April 1891; South Australian Register, 9 May 1891.

23 South Australian Register, 25 April 1891.

24 Northern Territory Times \& Gazette, 10 April 1891.

25 Northern Territory Times \& Gazette, 31 July 1891. 
the feet of the nimble dancers stop and go with the regularity of clockwork ... not the least interesting feature of the corroboree was the grotesque way in which many of the leading characters were painted up and fancifully decked out'. ${ }^{26}$

After their return to Adelaide, Edward Stirling sent Kintore 77 objects from a larger collection of objects acquired at various locations on their transcontinental trip. The rest of the objects were lodged at the South Australian Museum, where they remain. They include a 5-metre-long ceremonial pole and 10 of the 'curious and fantastic plaited helmets' collected by Stirling that were worn at the 1891 corroboree. $^{27}$

Mr Knight died suddenly in office in early 1892 and Inspector Foelsche appears to have been responsible for entertaining important visitors until the new Resident arrived. In March 1892, Lord Onslow, the ex-governor of New Zealand, visited Darwin, as part of a group on a regular cruise organised by Thomas Cook \& Co. on the SS Airlie. Foelsche received a telegram from Cooktown requesting that he treat the Onslows to a corroboree when they arrived. ${ }^{28}$ The Northern Territory Times o Gazette noted:

it was rather singular that some of the darkies engaged should have had cunning enough to borrow the picturesque head dresses used at a former spree, but afterwards sold to white residents, from whom they borrowed them. If the owners of these adornments continue good natured the fantastic hats will become in time quite stage properties. $^{29}$

In March 1893 the new Resident, Mr Justice Charles Dashwood, hosted the visit of Lord and Lady Jersey (the ex-governor of New South Wales and his wife) and another 'grand aborigine corroboree' was organised in their honour. ${ }^{30}$ The local paper reported that 'all the town and its wife [presumably the women of Darwin] turned out. The visitors watched the proceedings with evident enjoyment for halfan-hour or better, and will doubtless take away a few specimens of the decorative faculties of North Australian natives'. ${ }^{31} \mathrm{Mr}$ Dashwood told Lady Jersey:

this was one of the few places where such an entertainment was possible. In parts of Australia farther south the aboriginals have become too civilised, and in the wilder places they were too wild and would not perform before white men.

26 Northern Territory Times \& Gazette, 31 July 1891.

27 A brief list of these 77 items sent to Kintore prepared by museum preparator Amandus Zeitz dated 28 October 1894 is available in the South Australian Museum and Marischal Museum, Aberdeen. The online catalogue of Marischal Museum provides brief details of all their Australian objects, but further research is required to confirm provenance of the various Kintore collections. An exhibition, 'A Journey of Great Interest', was prepared by Philip Jones in 1991, to mark the centenary of this transcontinental expedition. See object label text sent from Jones to author.

28 Northern Territory Times \& Gazette, 18 March 1892.

29 Northern Territory Times \& Gazette, 18 March 1892.

30 Express \& Telegraph, 15 March 1893; Northern Territory Times \& Gazette, 17 March 1893.

31 Northern Territory Times \& Gazette, 17 March 1893. 
Lady Jersey noted:

The whole thing was well worth seeing. The men were almost naked, and had with their own blood stuck wool in patterns on their black bodies. They had tall hats or mitres of bamboo on their heads, and carried long spears. The Corroboree began after dark, and the men shouted, danced, and carried on a mimic war to the glare of blazing bonfires. A sort of music of rhythmic noise accompanied the performance caused by weird figures painted with stripes of white paint who were striking their thighs with their hands. They looked so uncanny that I could not at first make out what they were, but was told they were the women or 'gins'. The scene might have come out of the infernal regions or of a Witches' Walpurgis Night. ${ }^{32}$

The next day, Lord Jersey wanted to give the performers 'presents' but was 'begged not to give them money, as they would spend it in drink, but he was allowed to purchase tobacco and tea and distribute packets of tea' ${ }^{33}$ Lady Jersey found it hard to believe that the 'tidily dressed' and 'peaceable men and women' were the 'demoniac warriors who had thrilled us night before'. ${ }^{34}$

Thus, by April 1893, when the Countess of Kintore arrived in Darwin, the gubernatorial corroboree was becoming a regularly staged event.

\section{The 1893 corroboree}

Sydney Charlotte Keith-Falconer (née Montagu) (1853-1932), Countess of Kintore, was the wife of the then governor of South Australia and one of the great world travellers of her era. She arrived in Adelaide in 1889, and although her husband remained as governor till 1895, she returned to live in the United Kingdom in 1893. Returning by ship via the Endeavour River and the Torres Strait, she arrived in Port Darwin on 24 April 1893 for a brief stopover. The Russian survey ship the Razboinik was also in port, collecting hydrographical data and natural history specimens at Exmouth in Western Australia, and were undertaking a demographic survey of the Darwin population.

The Countess, her daughters Lady Ethel and Lady Hilda, Inspector Foeslche, as well as Commander Ukhtomsky from the Russian ship dined that night at the Residency. Commander Ukhtomsky felt he received 'exceptional courtesy' from the Resident $\mathrm{Mr}$ Dashwood, who had shown him all the places of interest and then had 'honored me by lunch and ball and, finally, arranged a military dance of the wilds - "karabora" for which the local savages had been summoned in the yard of the Governor's house'. ${ }^{35}$ The Advertiser described this event as a 'monster corroboree' organised especially for

32 Child-Villiers 1922: 325-26.

33 Child-Villiers 1922: 326.

34 Child-Villiers 1922: 326.

35 Windle et al. 2016: 186-87. 
Lady Kintore, ${ }^{36}$ and the Northern Territory Times \& Gazette commented this was 'a now recognised species of entertainment for visiting bigbugdom'. The audience included 'pretty well the whole European population of the township, together with the inevitable medley of Chinese, Malays, Japanese, Hindoos, and the other descriptions of humanity common to a free and enlightened community ${ }^{37}$

In addition to the performers, over 700 people attended. Outside the Residency gate, the Countess observed:

a party of blacks painting themselves for tonight's Corroboree - they were camped in front of a sumptuous wurley made of green boughs $\&$ leaves $\&$ were all intently sticking tufts of wool over backs \& chests. They gash themselves quite deeply \& with the blood stick the wool onto the spot till they too look as if they were dressed in tightly fitting jackets ... In the garden was another tribe - the lubras painting up their faces with white mixture to a positively gruesome state of hideousness $\&$ the men busy with blood $\&$ wool ... I should say they are very low down in the scale of humanity with their matted black hair, dirt $\&$ general wretchedness. ${ }^{38}$

There were three Aboriginal groups: 'The Larrakeahs (or Port Darwin tribe), the Woolnas (from Adelaide River) \& the Alligators'. The audience formed a circle and the corroboree began:

The lubras are seated together in a group near the fire. They keep up a monotonous kind of droning beating time with their hands \& which they bring down with a sort of hollow sound into their laps.... From the wurley on our left advance a company of warriors their backs covered with wool (as described) $\&$ on their heads the most extraordinary conical hats, made of grass, wool $\&$ feathers. With stealthy steps they steal out towards the fire \& then advance on the pole - beating time with their feet so perfectly that no metronome could do it better. The noise made by their feet is most astonishing - they might be a regiment of artillery - one of their numbers swarms up the pole - all in strict time, while the others go through their dance at the bottom ... Then the Larrakeahs retire $\&$ the Alligators advance - stamping all together the muscles of their thin legs quite tense but never a mistake in time, till they in turn retire with a wild whoop. Variations on the original thence take place - all to the same weird music?, \& all with apparently the same motif - defiance of their enemies ... Once they are wound up they would go on all night Mr Foelsche says. ${ }^{39}$

The corroboree ended about $10.30 \mathrm{pm}$. Inspector Foelsche remarked to the Countess: 'I was sorry there was a moon ... as it is weirder when there is nothing but the firelight'. She replied: 'Possibly it is but for my part I enjoyed it hugely as it was'.

36 Adelaide Advertiser, 25 April 1893.

37 Northern Territory Times \& Gazette, 29 April 1893.

38 Sydney Keith-Falconer (Countess of Kintore), Journal, 24 April 1893, University of Aberdeen Library, MS3064/3/9/1(6).

39 Keith-Falconer, Journal, 24 April 1893. The question mark is in the original text. 
Some present recalled memories of past events. One of the Aboriginal men asked Inspector Foelsche to point out Lady Hilda and Lady Ethel, as daughters of the Earl for whom they remembered performing the corroboree two years before. Down on the jetty before their boat departed the next morning, the vice-regal party saw 'a few of our town entertainers of last night smoking and lazily diving for pennies', including an Aboriginal youth from the interior who had crossed the continent with Kintore in 1891 . He 'had a bright face \& was dressed like a European', and had brought a small boy from Charlotte Waters with him who was working locally as a servant. ${ }^{40}$ At $11 \mathrm{am}, 18$ hours after their arrival, they set sail for home via Hong Kong, Japan and Canada.

Sydney Keith-Falconer acquired many objects from the corroboree, which she displayed in a small museum in her house at Keith Hall, near Inverurie, Aberdeenshire. In 1922, she donated these and other objects to Marischal Museum at the University of Aberdeen. ${ }^{41}$ They include a 3.6-metre-high painted ceremonial pole, decorative ornaments of feathers and wool, 14 tall conical headdresses and corroboree caps. ${ }^{42}$ The collection also includes a bushman's stool as well as an umbrella stand painted with scenes of the corroboree.

The construction and materials used in the ceremonial objects are revealing. The ceremonial pole is finely carved and painted with designs in red, white, black and yellow ochres along its length and decorated with feathers. The headdresses are made of many materials, both European and locally available. The foundations are made from a type of cane, wicker or grass, and they are decorated with many materials including feathers, wool, European cloth, various gums and seeds. Some have pompoms attached, which must have come from European homes. The colouring used in decoration includes the use of Reckitts Blue and red dye. The production of these objects clearly reflect the innovative use of available materials and the closeness of Aboriginal people to the domestic lives of Europeans in Darwin in 1893, either as domestic workers or close neighbours. A great deal of time and care would have been needed for their production.

\footnotetext{
40 Although Sydney Keith-Falconer records in her journal that she had 'Kodaked' the performers, no image of it has yet been located. Her scrapbook contains one poor-quality image of the Aboriginal youths on the jetty. Keith-Falconer, Scrapbook, University of Aberdeen Library MS3064/2/8/3.

41 Further donations from the family were given by after the death of the 10th Earl, in 1935, and again in 1936 through his secretary.

42 The author noted 12 of the 14 headdresses in the collection at Aberdeen in 2016. The ceremonial pole is registered as ABDUA:57077.
} 


\section{Values and meanings}

The Countess clearly enjoyed the corroboree, but what it meant for the performers is hard to assess as newspaper and diary accounts present only European perceptions of it and there are no Aboriginal accounts. In 1912, W. Baldwin Spencer lamented that the Larrakia were 'much too decadent to retain more than vestiges of old customs' and that 'it was unfortunate that no account of their ceremonies had been written'. ${ }^{43}$ Such views, as Povenellli notes, long persisted in relation to Larrakia ritual, rather than, as often with other groups, change being seen as dynamic and contributing to continuity of cultural traditions. ${ }^{44}$

The 1891 corroboree performed for the Earl of Kintore was mentioned only in the briefest terms by Edward Stirling. He noted it took place in front of the Residency between 8 pm and 9 pm:

Members of the two tribes of the vicinity the Larikiah \& the Woolnah took part - each contingent dressed or rather undressed for the occasion \& appropriately ornamented for the occasion. It was undoubted [sic] well done for semi-civilized blacks and their strange antics and manoeuvre which would require a separate description were carried out with great spirit. ${ }^{45}$

Stirling, who collected objects from the 1891 event, recognised in his 1894 report of the Horn expedition that even 'ordinary' corroborees required adherence to proper decorations, songs and music for what were still very elaborate performances. ${ }^{46}$

In 1882, Foeslche noted of Aboriginal ceremonies in northern Australia that 'corrobories' were performed on many occasions such as a death, start of hostilities, when returning from visits to neighbouring groups or 'when they feel inclined to be jolly. ${ }^{47}$ Different decorations were applied to the body for different ceremonies with specific colours for those in honour of the dead and 'on all other occasions any colour they fancy, which sometimes takes hours to put on, and covers the whole body, when they very much resemble in appearance the clowns in circuses' ${ }^{48}$ Parkhouse, a local government official in Darwin, noted in the 1890s that Aboriginal people came and went according to various seasonal factors, with corroborees performed for many different reasons including marriage and initiation. ${ }^{49}$

\footnotetext{
43 Foelsche 1882: 6; Spencer 1914: 152.

44 Povinelli 1993: 78 .

45 Edward Stirling, Diary, 2 April 1891, South Australian Museum Archives. Philip Jones has commented that as Kintore's expedition left at 2-3 am next morning, no fuller description seems to have been made.

46 Stirling 1896: 71.

47 Foelsche 1882: 5.

48 Foelsche 1882: 5.

49 Parkhouse 1895: 6-7.
} 
Wells has researched extensively the relationship of Larrakia to their lands. She notes that, since the early 1870s, Larrakia people had participated in public ceremonies and spear-throwing demonstrations associated with European events. These included the erection of the first telegraph pole in Darwin in 1872 and Boxing Day 'sports' festivities in $1873 .{ }^{50} \mathrm{With}$ increasing numbers of tourists visiting regularly by ship from the 1890s, public corroborees became more common and continued into the early twentieth century. ${ }^{51}$ She notes also how Larrakia had to negotiate radical changes to their landscape, resources and traditional economy due to the influx of Europeans living on their land together with increasing numbers of Aboriginal visitors coming into Darwin for short- and long-term visits. ${ }^{52}$ She suggests there was both a degree of alliance between Larrakia people and their colonisers against visiting traditional Aboriginal enemies, as well as increased potential for social and ceremonial activity by Larrakia and neighbouring groups. ${ }^{53}$ This appears similar to processes that Newton has described for south-eastern Australia, where nineteenthcentury corroborees were sometimes stimulated by increased mobility and more frequent gatherings caused by dislocation: when beliefs were being challenged and a new foreign social order was imposed, ritual was used as a creative response to change. ${ }^{54}$

Mary Rose Casey has commented that long before and after European colonisation, groups in a region gathered regularly to exchange objects, stories, ritual items and other objects, and argues that the terms of public performances in the late nineteenth century were constantly being negotiated. ${ }^{55}$

While the corroborees reported for early 1890s Darwin were prompted by viceregal and other visits and involved some organisation by local European residents such as Foelsche or the Government Resident, it would be simplistic to categorise the corroboree for the Countess in Michael Parson's terms, as either a 'tourist corroboree' or a 'command performance' in her honour. The accounts of the detailed preparations, the sequence of each group's participation and the skilful choreography observed, suggest it was done in accord with local Aboriginal traditions, with each group involved having particular roles and responsibilities. It was performed by Larrakia on their land and involved neighbouring groups with whom there were longstanding complex and constantly negotiated relationships.

\footnotetext{
50 Wells 2003: 165-66.

51 These included visits by the SS Australian in 1899, SS Chingtu in 1891, SS Guthrie 1894, SS Eastern in 1900; see Wells 2003: 168-69.

52 Wells 2003: 145-46.

53 Wells 2003: 146.

54 Newton 2017: 130.

55 Casey 2011: 11.
} 
Descriptions noted above of other corroborees in 1890s Darwin suggest the performers likely received some form of payment, probably in the form of goods rather than money. Although being a means of participation in the changing local economy, the elaborateness of the preparations suggest they held inherent value for the performers for their own cultural political and reasons, and were occasions of enjoyment for the participants (inferred from the European observation of a 'rare fine joke'). The ceremonial objects used ('stage properties') were objects of dynamic exchanges between the performers and local Europeans. After being made by Aboriginal people, they sold them to local residents, borrowed them for reuse and then possibly sometimes sold them again to visiting Europeans. The accounts indicate that with more notice of a forthcoming performance, more complex and decorative objects were produced, and it seems that keeping these to hand in European homes was a way to preserve them for future use as required.

\section{'What has been lost is safe'}

Anthropologist Howard Morphy has commented that ethnographic collections contain two locals: 'the local of the museum and the displaced local of the source community where objects originate. In recent years those two locals have come together and often found that they need to repair a spatiotemporal disjunction' ${ }^{56}$ From the point of view of the 'displaced local' of Aberdeen, in the time since these objects were donated to Marischal Museum in 1922, they have not been well understood, and known primarily as associated with a high-status local collector who was part of the vice-regal colonial networks in the late nineteenth century. The Countess was one of many vice-regal people, although notable as a rare woman, bringing back objects acquired from Indigenous peoples to the United Kingdom. ${ }^{57}$ Until this research was undertaken, curators at the South Australian Museum in Adelaide understood the objects in Aberdeen were some of the objects used at the 1891 corroboree for the Earl and given to him by Edward Stirling rather than being from a separate event organised for the Countess.

These materials comprise a rare set of nineteenth-century regalia used in a public corroboree by Aboriginal people, and perhaps the only one arranged in honour of a woman. The collection adds to the small body of surviving works used in public performances by Aboriginal people in the nineteenth century, which also includes the objects from the 1868 Aboriginal cricket team in the Royal Albert Memorial

\footnotetext{
56 Morphy 2015: 367.

57 She also collected objects directly from Māori during her Antipodean travels, which are also housed in Marischal Museum. Other vice-regal collectors include the governor of New Zealand, William Hillier (Lord Onslow), who in 1892 took to the United Kingdom a complete Māori meeting house, Hinemihi, which still stands today at Clandon Park in Surrey. Objects collected by Jane, Lady Franklin, Sir Thomas Brisbane, Sir Napier Broome, Sir Hugh Nelson and other state governors are distributed in various collections in the United Kingdom.
} 
Museum in Exeter, and artefacts used by Aboriginal people in Archibald Meston's 'Wild Australia Show' in the 1890s, now housed in the Australian Museum in Sydney.

The objects from the 1891 and 1893 corroborees form an important part of the heritage of Larrakia and neighbouring groups. Many objects used in non-public ceremonies were often left to decay naturally after performances, but the objects from the 1893 corroboree were made, used, stored, reused and then collected by an interested outside observer and have been kept since in private hands and in a public museum.

There is still much work to be done to identify and document the provenance and history of these and other Australian objects in Aberdeen. ${ }^{58}$ For example, a comparative analysis of the form, construction and materials of the objects from the 1891 corroboree in Adelaide and the ones from the 1893 corroboree in Aberdeen could provide insights into any differences of style in these objects and performances.

The question of what these objects mean for Larrakia and neighbouring peoples today also remains to be explored. The study of such historical objects in museums raises practical and ethical issues about relationships between researchers, museums that hold such items and the communities from which they originate. Where collections and peoples are at a great distance from each other, this may not always be a straightforward or quick process to undertake. The first step is raising awareness of the existence of the objects. The value of rich collaborative exchanges between museum collections and Indigenous communities is now widely recognised, as the work of artists such as Judy Watson, Abe Muriata, Maree Clarke, Jonathan Jones and Julie Gough attests, as well as being of value to community members with individual research interests. ${ }^{59}$ How to foster such relationships internationally is part of the research project to which this study contributes. There is much potential for further investigations by the Indigenous Research Fellows involved in the study working with regional collections in Britain.

At this point, we do not know if Larrakia people sold the ceremonial corroboree objects to Lady Kintore, if they were a gift to her from the Resident Mr Knight or perhaps Inspector Foelsche, or precisely how they left their original lands. One of the

58 At the University of Aberdeen, Kirsty Kernohan commenced a PhD in 2017 investigating the broader collecting activities of the Countess.

59 For illustration of works inspired by objects in museum collections by Judy Watson, Julie Gough, Jonathan Jones, Abe Muriata and Maree Clarke, see Gough 2018; Sculthorpe et al. 2015; Thorner 2018; and Watson 2009. 
clan mottos of the Earls of Kintore is: 'Quae amisassa salva' ('what has been lost is safe'), referring to the crown jewels of Scotland. ${ }^{60}$ At a memorial service in 1932, Rev. Grant said:

We might think of Lady Kintore ... as the wife of a former Governor of South Australia, who enhanced the prestige of that onerous position, and endeared herself to the colony by her charm, or we might remember her in the role of a traveller, intrepidly braving by the Amazon, or in Indo-China, hardships that might wellappal even a man half her age. ${ }^{61}$

Although Sydney Keith-Falconer spent less than a day in Darwin, through the preservation of the ceremonial regalia from the corroboree put on in her honour, we might now also recognise her as playing a role in documenting the lives of Aboriginal people in multicultural Darwin in the late nineteenth century, leaving a material legacy now ready to be enlivened by Aboriginal people with new relationships and perspectives in the twenty-first century.

\title{
References
}

\section{Newspapers}

\author{
Aberdeen Press and Journal \\ Adelaide Advertiser \\ Adelaide Observer \\ Express \& Telegraph (Adelaide) \\ The Mail (Adelaide) \\ Northern Territory Times \& Gazette \\ South Australian Register
}

\section{Unpublished sources}

Jones, Philip 1991, “'A Journey of Great Interest”: The Centenary of Kintore and Stirling's Expedition Across Australia in 1891', Unpublished labels and documentation for exhibition, South Australian Museum, Adelaide.

Jones, Philip 2001, 'To Study Aboriginal Collections in European Museums', unpublished report, The Winston Churchill Memorial Trust, South Australia. Available at www. churchilltrust.com.au/media/fellows/Jones_Philip_2001.pdf (accessed 27 January 2018).

60 These were, reputedly, preserved from falling into the hands of Cromwell by the mother of the first Earl. The Mail, 24 March 1928.

61 Aberdeen Press and Journal, 27 September 1932. 
Keith-Falconer, Sydney Charlotte (Countess of Kintore) Journal. Vol. 162. Special Collections, Library, University of Aberdeen MS3064/3/9/1(6).

Keith-Falconer, Sydney Charlotte (Countess of Kintore). Scrapbook. Special Collections, Library, University of Aberdeen MS3064/2/8/3.

Stirling, Edward, Diary, 1891, South Australian Museum Archives.

\section{Published sources}

Cahir, D. and Ian D. Clark 2010, 'An edifying spectacle': A history of 'tourist corroborees' in Victoria, Australia, 1835-1870', Tourism Management 31(3): 412-20. doi.org/ 10.1016/j.tourman.2009.04.009.

Casey, Maryrose 2011, 'Cross-cultural encounters: Aboriginal performers and European audiences in the late 1800s and early 1900s', Double Dialogues 14: 1-13, www. doubledialogues.com/article/cross-cultural-encounters-aboriginal-performers-andeuropean-audiences-in-the-late-1800s-and-early-1900s/ (accessed 25 July 2018).

Child-Villiers, Margaret Elizabeth Leigh, Countess of Jersey 1922, Fifty-One Years of Victorian Life, J. Murray, London.

Cooper, Carol 1989, Aboriginal and Torres Strait Islander Collections in Overseas Museums, Aboriginal Studies Press, Canberra.

Foelsche, Paul 1882, 'Notes on the Aborigines of Northern Australia', Transactions of the Royal Society of South Australia 5: 1-18.

Gathercole, Peter and Alison Clarke 1979, Survey of Oceanian Collections in Museums in the United Kingdom and the Irish Republic, UNESCO, Paris.

Gosden, Chris, Frances Larson and Alison Petch 2007, Knowing Things: Exploring the Collections at the Pitt Rivers Museum, 1884-1945. Oxford University Press, Oxford.

Gough, Julie 2018, Fugitive Histories, University of Western Australia Publishing, Perth.

Jones, Philip 2005, The Policeman's Eye: The Frontier Photography of Paul Foeslche, South Australian Museum, Adelaide.

Jones, Philip 2007, Ochre and Rust: Artefacts and Encounters on Australian Frontiers, Wakefield Press, Kent Town.

McBryde, Isabel 1978, 'Museum collections from the Richmond River district of Aboriginal artefacts', in Records of Times Past: Ethnohistorical Essays on the Culture and Ecology of the New England Tribes, Isabel McBryde (ed.), Australian Institute of Aboriginal Studies, Canberra.

McKay, Judith and Paul Memmott 2016, 'Staged savagery: Archibald Meston and his Indigenous exhibits', Aboriginal History 40: 181-203. doi.org/10.22459/AH.40.2016.07. 
Megaw, J.V.S. 1993, 'Something old, something new: Further notes on the Aborigines of the Sydney district as represented by their surviving artefacts and as depicted in some early European representations', Records of the Australian Museum, Supplement 17: 25-53. doi.org/10.3853/j.0812-7387.17.1993.57.

Megaw, J.V.S. 1994, 'There's a hole in my shield”: A textual footnote', Australian Archaeology 38: 35-37. doi.org/10.1080/03122417.1994.11681517.

Moore, David R. 1984, The Torres Strait Collections of A.C. Haddon, British Museum Press, London.

Morphy, Howard 2015, 'The displaced local: Multiple agency in the building of museums' ethnographic collections', in The International Handbooks of Museum Studies: Volume 1, Museum Theory, Andrea Witcomb and Kylie Message (eds), Wiley Online Library: 365-87. doi.org/10.1002/9781118829059.wbihms118.

Morphy, Howard and Elizabeth Edwards (eds) 1988, Australia at Oxford, Pitt Rivers Museum, Oxford.

Newton, Janice 2017, 'Two Victorian corroborees: Meaning making in response to European intrusion', Aboriginal History 41: 121-49. doi.org/10.22459/AH.41.2017.06.

Nugent, Maria and Gaye Sculthorpe 2018, 'A shield loaded with history: Encounters, objects and exhibitions', Australian Historical Studies 49: 28-43. doi.org/10.1080/103 1461X.2017.1408663.

Parkhouse, T.A. 1895, Native Tribes of Port Darwin and its Neighbourhood, Australian Association for the Advancement of Science, Brisbane.

Parsons, Michael 1997, 'The tourist corroboree in South Australia to 1911', Aboriginal History 21: 46-69.

Philp, Jude 2015, 'KRAR: Nineteenth century turtle-shell masks from Mabuyag collected by Samuel McFarlane', Memoirs of the Queensland Museum - Culture 8(1): 99-125.

Plomley, N.J.B. 1961, 'Tasmania Aboriginal material in collections in Europe', Journal of the Royal Anthropological Institute of Great Britain and Ireland 91(2): 221-27. doi.org/ $10.2307 / 2844414$.

Plomley, N.J.B. 1964, 'A list of Tasmanian material in collections in Europe', Records of the Queen Victoria Museum and Art Gallery, n.s., 15: 18pp.

Povinelli, Elizabeth A. 1993, Labor's Lot: The Power, History and Culture of Aboriginal Action, University of Chicago Press, Chicago and London.

Rosenzweig, Paul 1996, The House of Seven Gables: A History of Government House, Darwin, Historical Society of Northern Territory, Darwin.

Sculthorpe, Gaye 2016, 'Finding Aboriginal lives in United Kingdom museum collections: Artefacts from the 1868 cricket tour of England', Australian Aboriginal Studies 1: 85-91. 
Sculthorpe, Gaye, John Carty, Howard Morphy, Maria Nugent, Ian Coates, Lissant Bolton and Jonathan Jones 2015, Indigenous Australia: Enduring Civilisation, British Museum, London.

Spencer, W. Baldwin 1914, The Native Tribes of Northern Australia, MacMillan \& Co., London.

Stirling, Edward Charles 1896, 'Part IV Anthropology', In Report of the Horn Expedition Scientific Expedition to Central Australia, Baldwin Spencer (ed.), Dulau, London \& Melville, Mullen \& Slade, Melbourne.

Taylor, Rebe 2017, Into the Heart of Tasmania: A Search for Human Antiquity, Melbourne University Press, Melbourne.

Thomas, Nicholas 2018, 'A case of identity: The artefacts of the 1770 Kamay (Botany Bay) encounter', Australian Historical Studies 49(1): 4-27. doi.org/10.1080/103146 1X.2017.1414862.

Thorner, Sabra 2018, 'The photograph as archive: Crafting contemporary Koorie culture', Journal of Material Culture online: 1-26, doi.org/10.1177/1359183518782716 (accessed 27 July 2018).

Watson, Judy 2009, Judy Watson: blood language, Miegunyah Press, Melbourne.

Wells, Samantha 2003, 'Negotiating Place in Colonial Darwin: Interactions between Aborigines and whites, 1869-1911', PhD thesis, University of Technology Sydney.

Wilson Helen J., Barbara James and David Carment 1994, The Real Live Resident: The Annotated Letters of John George Knight, 1888-1892, self-published, Darwin.

Windle, Kevin, Elena Govor and Alexander Massov 2016, From St Petersburg to Port Jackson: Russian Travellers' Tales of Australia 1807-1912, Australian Scholarly Publishing, Melbourne. 
This text is taken from Aboriginal History, Volume 42, 2018, edited by Ingereth Macfarlane, published 2018 by ANU Press, The Australian National University, Canberra, Australia.

doi.org/10.22459/AH.42.2018.03 